NBER WORKING PAPER SERIES

\title{
THE MEDIAN VOTER AND THE MEDIAN CONSUMER: LOCAL PRIVATE GOODS AND RESIDENTIAL SORTING
}

\author{
Joel Waldfogel \\ Working Paper 11972 \\ http://www.nber.org/papers/w11972 \\ NATIONAL BUREAU OF ECONOMIC RESEARCH \\ 1050 Massachusetts Avenue \\ Cambridge, MA 02138 \\ January 2006
}

I thank Zell-Lurie Center at Wharton for financial support. Jon Moon and Andrew Ly provided excellent research assistance. Joe Gyourko, Jeff Milyo, and Albert Saiz provided very helpful input. The views expressed herein are those of the author(s) and do not necessarily reflect the views of the National Bureau of Economic Research.

(C2006 by Joel Waldfogel. All rights reserved. Short sections of text, not to exceed two paragraphs, may be quoted without explicit permission provided that full credit, including (C) notice, is given to the source. 
The Median Voter and the Median Consumer: Local Private Goods and Residential Sorting Joel Waldfogel

NBER Working Paper No. 11972

January 2006

JEL No. L1, L8, R3

\section{ABSTRACT}

When a product's product provision entails fixed costs, it will be made available only if a sufficient number of people want it. Some products are produced and consumed locally, so that provision requires not only a large group favoring the product but a large number nearby. Just as one has an incentive to sort into community whose median voter shares his preferences for local public goods, product markets may provide an analogous incentive to sort into a community whose consumers tend to share his preferences in private goods. Using zip code level data on chain restaurants and restaurants overall, this paper documents how the mix of locally available restaurants responds to the local mix of consumers, with three findings. First, based on survey data on chain restaurant patronage, restaurant preferences differ substantially by race and education. Second, there is a strong relationship between restaurants and population at the zip code level, suggesting that restaurants' geographic markets are small. Finally, the mix of locally available chain restaurants is sensitive to the zipcode demographic mix by race and by education. Hence, differentiated product markets provide a benefit - proximity to preferred restaurants - to persons in geographic markets whose customers tend to share their preferences.

Joel Waldfogel

Public Policy and Management University of Pennsylvania, Wharton School 3100 Steinberg Hall-Dietrich Hall Philadelphia, PA 19104-6372 and NBER waldfogj@wharton.upenn.edu 
When fixed costs are large relative to market size and preferences differ across individuals, then consumers get what they want only to the extent that others also want it. This creates a benefit from participating as a customer in markets with others sharing similar tastes to allow access to appealing products. Economists have long understood this explicitly in the context of publicly provided goods, such as elementary schools or police protection. Because local public goods are allocated through collective choice, the median voter determines the amount of spending on, say, schools in each municipality. Potential residents then choose among communities and select the one that best matches their tastes. The resulting "Tiebout sorting" has people agglomerating into communities with others sharing their preferences for local public goods.

Of course, people consume vastly more commercial than publicly provided local goods and services. ${ }^{1}$ Research on residential sorting puts private consumption in the background by assuming that private goods are equally available in all locales. Private goods and services are implicitly assumed to be ubiquitously available, perhaps because they are produced at constant returns, so that location choice does not affect access. Yet, this is certainly not true. A potentially important factor overlooked in previous research is the role of commercial markets for differentiated product in rewarding and perhaps promoting the agglomeration of persons sharing similar preferences for private products. ${ }^{2}$ When the provision of a product entails fixed costs, it will be made available only if a sufficient number of people want it. When the product is difficult to trade across space a "local private good" - its provision requires not only a large number of people favoring the product, but a large number nearby.

\footnotetext{
${ }^{1}$ Local property taxes totaled $\$ 264$ billion in 2001 , less than 4 percent as high as personal consumption expenditures of $\$ 6.9$ trillion (see ERP, 2004).

${ }^{2}$ For brevity I use the term "product" to describe both goods and services.
} 
If the provision of appealing commercial products depends on the distribution of local tastes, then product markets can provide a rationale alongside local public goods for sorting. Just as one has an incentive to sort into community whose median voter shares his preferences local public goods, markets may provide an analogous incentive to sort into a community whose median consumer shares his preferences in local private goods.

Recent research documents that different groups (e.g. blacks and whites, Hispanics and non-Hispanics) have starkly different preferences in a number of product categories (Waldfogel, 2003, 2004; George and Waldfogel, 2003). For example, blacks and whites have starkly different preferences in radio and television programming, as well as newspaper content. Because these products have large fixed costs, whether a metro area has, say, a black-targeted radio station requires the area to have a substantial black population. This mechanism, termed a "preference externality," increases the welfare of blacks as media consumers as their metro areas have more blacks. Although these products are local, media content has essentially zero transport costs within metro areas, so preference externa lities operating through this product market operate throughout MSAs, not only within neighborhoods.

Few topics have received as much attention from social scientists as the causes and consequences of residential segregation by race. US ghettoes formed as blacks migrated out of southern agriculture and into northern US cities prior to 1950 and were herded by white racism into particular neighborhoods. It appears that segregation is bad for black economic and social outcomes (Massey \& Denton, 1991; Cutler \& Glaeser, 1997). Yet, segregation is eroding only slowly. The slow erosion of segregation is somewhat surprising in light of both academic evidence and popular belief that urban life 
is inimical to health and success. Why would blacks choose to live in segregated neighborhoods, despite the apparent harmful effects of this choice on health, employment, single parenthood, and a host of other outcomes? No single factor is likely to serve as a convincing explanation. Racism, housing prices, neighborhood demographic composition all presumably still play a role, but local product markets may also promote residential segregation.

Since the diffusion of the Sears Catalogue in conjunction with mail delivery a century ago, or the widespread adoption of the Internet more recently, the disadvantages of residential isolation in access to "dry goods" has diminished. Even people who live far from concentrations of population - or from persons sharing their tastes - still have access to unlimited variety of books, CDs, clothing and other tradable items. And, indeed, there is evidence that isolated persons make relatively more use of the Internet and mail order channels to obtain such goods (Sinai and Waldfogel, 2004). For other, "perishable" goods, including many raw and prepared foods, residential location affects the ease - or feasibility - with which one can obtain items. The location of manufacturing is largely decoupled from the locations of consumption (think of automobiles, etc). For services, by contrast, this decoupling is more difficult. An extreme example illustrates the point. Jewish law requires a minyan of 10 men to conduct a religious service. Moreover, Orthodox Jews are not allowed to drive during the Sabbath. As a result, observant Orthodox Jews must live walking distance from their synagogue. In this instance, the market for religious services gives rise to agglomeration of at least 10 male Orthodox Jews around each synagogue. 
This paper asks whether preference externalities operate through the restaurant market. This industry provides an auspicious context for study because restaurants geographically couple production and consumption. Under two simple conditions, the agglomeration of groups sharing food preferences will bring forth restaurants that appeal to the respective groups. First, food preferences must differ substantially between groups. Second, the fixed costs of operating restaurants must be sufficiently large that restaurants appealing to each group only arise with sufficient local concentrations of persons favoring a particular variety. Then neighborhoods with more members of a particular group will have more restaurants catering to the group's preferences.

It is by no means obvious that these conditions hold for this industry. First, restaurant fixed costs do not, on their face, appear very large. In the other industries where preference externalities have been documented, fixed costs are quite large relative to market size. The number of products per market provides a rough (implicit) measure of fixed costs in relation to market size. Daily newspaper markets typically have one or two products per market; radio markets have on average about 20 (across large US metro areas). Restaurants, by contrast, are far more numerous. There are 500,000 restaurants in the US, approximately 1 per 600 persons. A metro area of 1 million persons typically has about 1,500 restaurants. The fixed cost of operating a restaurant is of a lower order of magnitude. Yet, the market area of a restaurant may be much smaller than a metro area, so the large number of restaurants per MSA does not imply that fixed costs are small relevant to the size of the relevant market.

This paper proceeds in four sections. Section 1 sketches a simple product differentiation framework for thinking about preference externalities in this market and 
links the paper to the four literatures adjacent to this study. Section 2 describes the data used in the study (Reference USA for chains, Zipcode Business Patterns for total restaurants, Census 2000 for demographic data, Scarborough Research for data on restaurant chain patronage by race). Section 3 presents results. First, we show how restaurant preferences differ by race, Hispanic status, and education. Second, we explore the size of the relevant market area for restaurants. We document that the relationship between the number of restaurants in an area and market size, as measured by population, is very similar at highly aggregated (3-digit zipcode and finely disaggregated (5-digit zipcode) levels of geography. This suggests that restaurant markets are quite local. Third, I find that the contour of locally available products relates strongly to the distribution of local types by race, Hispanic status, and education/income. While most restaurants - and restaurants as a group - are less available in more heavily black, Hispanic, or less educated areas, some categories of restaurants (those catering to respective groups) are actually more available. This indicates that product markets bring forth what groups want to a greater extent as the groups agglomerate into relevant market areas. To put this another way, differentiated product markets provide a benefit to persons sorting into geographic markets whose customers tend to share their preferences.

\section{Background and Framework}

\section{Background}

This research stands at the confluence of three literatures in industrial and urban economics. First, this work is related to the literature on Tiebout (1956) sorting (Epple and Sieg, 1999) based on publicly provided goods, or in some cases housing and 
neighborhood attributes (Bayer, et al, 2002). Second, this work is related to the specific strand of the sorting literature on the causes (and consequences) of ghettoes (Massey and Denton, 1993; Cutler and Glaeser, 1997; Cutler, Glaeser, and Vigdor, 1999). Third, because of its focus on commercially rather than publicly provided goods, this work is related to the industrial literature on entry that relates the number of available products to market size (Bresnahan and Reiss, 1990, 1991; Berry, 1992). More recently, this literature has begun to treat space explicitly (Seim, 2003). ${ }^{3}$ Our focus on the differential appeal of products to heterogeneous consumers recalls work on "preference externalities" in media markets (Waldfogel, 2003, 2004; George and Waldfogel, 2003). Finally, this work relates to research on urban quality of life (Gyourko and Tracy, 1991) and to more recent research emphasizing the consumption benefits of agglomeration (Glaeser, Kolko, and Saiz, 2001; Berry and Waldfogel, 2003).

\section{Framework}

The relationship between the agglomeration of like individuals and available product variety results from joint process of a) individuals choosing where to live, and b) firms choosing where to locate their outlets. Causality could easily run both ways. Individuals might choose where to live, at least in part, based on the products available in a neighborhood. And, at the same time, firms choose where to place their outlets based on the patterns of agglomeration. ${ }^{4}$

\footnotetext{
3 The "central place theory" tradition in urban economics is similarly concerned with the location of shopping establishments. Christaller (1966) is the classic reference; Eaton and Lipsey (1982) provides a contemporary treatment of equilibria built up from maximizing behavior of consumers and firms. $4 \quad$ When viewed as a simultaneous move game - and starting from a blank slate - the entry residential location game can have multiple equilibria. To see this, suppose there are 2 each of two types of people ( $\mathrm{P}$ and $\mathrm{B}$ for pizza and burger lovers) and two locations ( $\mathrm{X}$ and $\mathrm{Y}$ ), each with room for 2 people.
} 
The history of black people in the US indicates that the entry and residential location game was never played on a blank slate (see Massey \& Denton, 1991; Cutler \& Glaeser, 1997). There is a well-documented history of discrimination and forced segregation into particular neighborhoods that replaces the first player's choice of a location in the blank slate. Evidence seems to suggest that, perhaps until recently, subsequent black players in this game were also compelled to choose particular neighborhoods. Under that view, the degree of agglomeration of like types of the data is exogenous, so that we can proceed to study its effect on patterns of entry. ${ }^{5}$

Taking the distribution of population as given, we can think about the entry process using a framework in the spirit of Hotelling (1929). Within a market area, suppose that restaurants are differentiated only by cuisine and that cuisine itself can be represented along a single dimension. To fix ideas, one might think about this dimension as the extent to which a restaurant is targeted to, say, blacks. Market areas differ in the distribution of their consumers' preferences (or most-preferred restaurant type). Suppose that white consumers' most preferred cuisine is distributed according to $F($ ), while black consumers are described by $G($ ). Suppose - against fact but in favor of simplicity - that

Suppose that pizza and burger outlets require 2 customers each to be viable. Firms would rather be viable than not exist. Finally, suppose that individuals only patronize restaurants in their location. They are happier with their preferred cuisine than with non-consumption. And they would rather consume nothing than the output of their non-preferred outlet.

This game has two equilibria, both with agglomeration of like individuals:

1) location $X$ can have 2 P's while $Y$ has 2 B's. In that case $X$ gets a pizza restaurant and $Y$ gets a burger restaurant.

2) Location $Y$ can have 2 P's while $X$ has 2 B's. In that case $Y$ gets a pizza restaurant and $X$ gets a burger restaurant.

Both of these outcomes make the consumers and firms as happy as possible. The other possible outcome, with $1 \mathrm{P}$ and $1 \mathrm{~B}$ in each location results in no entry and no consumption.

In this game, as soon as anyone has chosen a location, the equilibrium is assured. Suppose a $\mathrm{P}$ moves to location Y. Now a B has no incentive to move to $\mathrm{Y}$ because he will be assured of no local burger entry. Another P, however, is assured of pizza as long as he co-locates with the other P.

${ }^{5}$ If residential agglomeration is endogenous, the relationship between agglomeration of like individuals and entry still allows statements about the product options experienced by agglomerating individuals. 
each firm operates no more than one outlet in a market (to avoid multiproduct firm concerns). Whether entry occurs - and where the firm(s) will locate - depends on how consumers' willingness to patronize restaurants varies with their distance from their ideal.

Suppose that, because of fixed costs, each outlet requires 100 customers for viability. If the market area has fewer than 100 persons, no entry will occur. If the area has at least 100 persons, and people are willing to patronize any cuisine, then at least one restaurant will enter. If travel costs (among cuisines, not space) matter and the market can accommodate only one entrant, then it will locate where it can attract the most patrons. If the distribution of most-preferred cuisine locations is single-peaked, the firm will locate at the mode. The shape of the distribution of preferences determines the nature of the product available to all consumers. This is the product market analogue to what Mill (1978) termed the "tyranny of the majority" in collective choice. ${ }^{6}$ If the distribution of ideal cuisines were symmetric, the mode would be the median, and then the sort of person who would be most happy in this market would share the preferences of the median consumer.

As the population grows beyond 200, a second restaurant is viable. If customers have no "travel costs," then the second restaurant's location is indeterminate (given that prices are being treated as fixed). If travel costs matter, i.e. consumers prefer to patronize a restaurant nearer to their ideal, then firms' location decisions grow sensitive to the distribution of preferences. Moroever, the distribution of restaurant types available in the market grows sensitive to the respective populations of blacks and whites.

\footnotetext{
6 Friedman (1962) argues that reliance on markets avoids the tyranny of the majority, or that while the use of political channels "tends to strain the social cohesion essential for a stable society," the "widespread use of the market reduces the strain on the social fabric by rendering conformity unnecessary." (pp. 23-4)
} 
To say this more concretely, we need a way of characterizing entry equilibria. In general, problems of this type are made difficult by two things. First, firms are usually modeled as competing on price, given their entry position. A firm that can charge high prices can subsist with a smaller market than a firm facing competitive pressure on pricing. Second, characterizing equilibrium requires some assumption about commitment. If a firm has entered at location $x$, will it necessarily stay there in the face of competitive entry nearby?

Given our goal - showing how the distribution of available restaurant types can reflect the distribution of potential customers - we make the simplifying assumption that prices are fixed. Chain ownership may provide a fig leaf of justification for this assumption. Equilibrium occurs when no potential entrant wishes to enter and no existing firm wishes to exit. To make this concrete, we need a characterization of what a firm, located at $x$, gets as its payoff. Suppose $H($ ) is the cumulative density of potential customers. Suppose the nearest firms in product space are at $y$ and $z$, where $y<x<z$. Since customers patronze their nearest outlets, customers located between $(y+x) / 2$ and $(x+z) / 2$ will patronize the firm at $\mathrm{x}$ : Their patronage is therefore: $H((x+z) / 2)$ $H((x+y) / 2)$. Suppose fixed costs are such that the minimum patronage for viability is $K$. What are the conditions for equilibrium? First, any firm, such as the firm at $x$ must be viable. That is, $H((x+z) / 2)-H((x+y) / 2)>K$. Second, there must not be any space between $y$ and $z$ to allow another firm viability (assuming the firm at $y, x$, and $z$ remain where they are). These conditions simply dictate that outlets be neither too close nor too far from one another in equilibrium. Of course, the relevant distance is not 
literally the distance but rather then number of customers they each garner. Regions of product space with greater customer density will support more outlets in equilibrium.

Now decompose $H$ into its black and white components, $F$ and $G$. Different markets have different numbers of blacks and whites. Areas with more potential customers - more population - will have more outlets. In areas with lots of blacks, in particular, we expect a denser clustering in black-preferred regions of product space. In areas with more black-targeted outlets, blacks have options closer to their products-space ideal. In this more general context, a person need not share the median consumer's preferences to find an appealing product; however, there must be some concentration of consumers with similar preferences to ensure a variety that is nearby in product space. This is one version of what Spence (1976) terms the problem of "product selection." What is offered is what can attract a large base of customers.

This setup suggests the three questions we will examine empirically below: 1) do restaurant preferences differ across groups?; 2) how does the number of restaurants in a locale vary with population, at various levels of geographic aggregation - by extension, what is the de facto relevant market area?; and 3) is the mix of available products sensitive to the mix of potential consumers in the population?

\section{Data}

The basic dataset we employ to document the relationship between the mix of consumers and the available mix of restaurants is a 5-digit zipcode cross section with information on the total number of restaurants, the number of establishments in each of 136 fast food and sit down chain restaurants, and demographic variables such as total 
population and the share of population that is black, Hispanic, college-educated, and lowincome (households with under $\$ 40,000$ in annual income). We also aggregate the data to the four and three digit zipcode levels for some analyses. (For brevity we will use the term "zipcode" to describe 5-digit zipcodes). These data are drawn from three sources: Zipcode Business Patterns 2000, the 2000 Census, and Reference USA. We restrict attention to the nearly 15,000 zipcodes in metropolitan areas.

The ZBP data reports the number of restaurants in each 5-digit zipcode in 2000. We include all establishments in NAICS code 722, Food Services and Drinking Places (see http://www.census.gov/epcd/ec97/def/722.HTM). The total number of restaurants in the US in 1997 was 486,906, and these establishments had sales of \$252 billion nationally. Reference USA is a directory product that includes the address (including the zipcode) of every business in the US, including the outlets of the 136 major restaurant chains that we include in our sample. Collectively, these chains account for 107,500 metro area restaurants, or roughly one third of the 358,326 ZBP metro area restaurant locations in the US.

In addition, we have information from Scarborough Research on the whether each of 180,000 persons, in 66 large US markets, has patronized each of the 136 chain restaurants in the last 30 days. These data are drawn from surveys undertaken during 1999-2000. We know the respondents' race, Hispanic status, and education, allowing us to compare restaurant patronage patterns across these groups.

We are able to classify the chain restaurants by cuisine. Based on review of the chains' self-descriptions and menus, we classify the chains into burger, pizza, Mexican, chicken, and coffee/bagel restaurants. Most of the chains remain unclassified, however. 
Finally, using Consumer Reports 2003 restaurant survey, we can classify 52 of the sitdown chains by price range, including "the average amount readers paid for their own dinner and drinks, excluding tip" ( $<\$ 10, \$ 11-14, \$ 15-19, \$ 20-24, \$ 25-29, \$ 30+)$.

The top panel of table 1a summarizes our total restaurant and population data at various levels of geographic aggregation. The mean (median) population for our urban zipcodes is $15,450(9,965)$, while the mean (median) number of restaurants is $24.9(12)$. The mean black and Hispanic percentages are about 10, far above the medians of roughly 3. There is substantial variation across zipcodes in the demographic variables. For example, by race the $90^{\text {th }}$ percentile zipcode is nearly a third black; and by Hispanic status, the $90^{\text {th }}$ percentile zipcode is also nearly a third Hispanic. The mean and median college-educated percentage (of persons over age 25 ) is about 17 , while the $90^{\text {th }}$ percentile is nearly a third.

The remaining panels of table 1a repeat the exercise of the top panel at higher levels of geographic aggregation. There are 3960 metropolitan-area four-digit zipcode areas. Four-digit zips have mean (median) population of roughly 58,000 $(31,000)$ and a mean (median) of 94 (41) restaurants. There are 684 three-digit zipcodes, and they have mean (median) population of about 338,000 $(204,000)$ and a mean (median) of $545(335)$ restaurants. Despite their greater geographic aggregation, the three and four-digit zipcodes have as much variation in percent black, Hispanic, etc. as the 5-digit zips.

Table $1 \mathrm{~b}$ shows the number of restaurants in groups of sample chains, and their tendency to be present, in 5, 4, and 3-digit zip code areas. For example, 64 percent of 5digit zipcodes have at least one location of one of the 136 sample chains. Over half of 5digit zips have one of the burger chains, while less than a third have a chicken chain, and 
just over a quarter have a Mexican chain. At higher levels of aggregation, the tendency for each chain to be present rises. For example, 90 percent of 3-digit zips - areas averaging roughly 1000 square miles - have at least one of the chicken chains present, while only 31 percent of 5 digit zips - areas of 41 square miles - have at least one.

\section{Results}

Our discussion of results is divided into three areas. First, we present evidence on how restaurant preferences differ across groups. Second, we discuss the relationship between market size and restaurant entry overall, along with the related issue of market size. Finally, we present evidence on the relationship the types of restaurants available nearby and the local distribution of population by race, Hispanic status, and education and income.

\section{Do Restaurant Preferences Differ across groups?}

Before turning to data on restaurant patronage patterns of particular groups, it is useful to outline what information our question requires about preferences. We are interested, for example, in whether blacks derive product market benefit from living among blacks. For addressing whether members of a group benefit each other, it is sufficient to document unconditional differences in preferences across group. Some part of a difference in product choices across groups may be attributable to some other cause, such as income. If we wanted to say why, for example, blacks benefit each other through product markets, we would need to document not only that preferences differ across groups but also that they differ because of race. We provide some such evidence below, 
but we note that our argument - that people may affect each other through product markets - does not rely on causal differences in preferences.

\section{a. Race}

We have two means available to determine whether black and white food preferences differ. First, we can appeal to historical accounts of the development of African American cuisine in the American South. These sources describe slaves' development of a cuisine based largely on ingredients that their white masters did not deign to consume.

One account:

The fresh vegetables found in Africa were replaced by the throwaway foods from the plantation house... The slave diet began to evolve when slaves entered the plantation houses as cooks. With an array of new ingredients at their fingertips and a well-tuned African palate, the cooks would make delectable foods for their masters. Suddenly southern cooking took on new meaning. Fried chicken began to appear on the tables, sweet potatoes (which had replaced the African yam) sat next to the boiled white potato. ${ }^{7}$

The cuisines mentioned in these accounts fall under the categorie s of "Southern cuisine," as well as Creole and Cajun. Particular foods include fried chicken, various shrimp recipes, catfish, hush puppies, crab cakes, cornbread muffins, and buttermilk biscuits.

Some of these foods feature prominently in the offerings of chain restaurants. In particular, fried chicken is the featured offering of four major chains in our sample: KFC, Church's Fried Chicken, Bojangle's, and Popeye's Fried Chicken and Biscuits. Seafood is the featured food at Long John Silver's and Red Lobster. On the basis of the historical

${ }^{7}$ From "A History of Soul Food," http://www.foxhome.com/soulfood/htmls/soulfood.html (Accessed 8/18/2004). See also the Kraft Foods "African American Flavor Center," at http://www.kraftfoods.com/esi.net/african american/content.aspx? shortname=military \&a=87 
accounts, one might expect these restaurants to be disproportionately patronized by black consumers.

We can, of course, examine black and non-black consumers' patterns of restaurant patronage directly using the Scarborough data. For each of 136 restaurant chains, these data indicate whether respondents patronized the restaurant in the 30 days prior to the survey (surveys are filled out throughout the year between Fall 1999 and Spring 2000).

Tables 2 and 3 report the fraction of blacks and non-blacks patronizing each of the major chains in the past 30 days, and the results support the impression one would have from the historical accounts. ${ }^{8}$ Blacks are far more likely than whites to patronize chains offering Southern fare. Blacks are also somewhat more likely than whites to patronize Rally's and Checker's burger chains.

Some part of the difference between black and white patronage rates is attributable to "constraints" such as restaurant availability and income levels rather than "preferences" per se. While we do not know the location of blacks with the 66 metro areas covered by Scarborough, we do know income, age, gender, etc. We can estimate probits on, say, the tendency to patronize KFC on race as well as the other observables in order to soak up the variation in patronage associated with location and income (as distinct from preferences). When we do this, there remain substantial and statistically significant race differences. After accounting for available observables - including MSA fixed effects, gender, and dummies for 5-year age ranges - blacks are roughly 20 percentage points more likely (2 times as likely at KFC and 3 times as likely at Popeye's)

\footnotetext{
${ }^{8}$ We include in the table only chains that respondents report patronizing in at least 20 of the 66 surveyed markets.
} 
to patronize the chicken chains than whites. On the basis of evidence in tables 2 and 3 , blacks and whites appear to have different preferences in prepared food. ${ }^{9}$

\section{b. Hispanic Status}

While the term "Hispanic" covers a broad range of national backgrounds, nearly 60 percent of US Hispanics are of Mexican extraction. ${ }^{10}$ One might therefore expect that Mexican restaurants cater to Hispanic tastes, although casual observation suggests that non-Hispanic consumers are major patrons of Mexican restaurants.

Tables 2 and 3 show that the Hispanic tendency to patronize listed Mexican restaurants is higher than the non-Hispanic tendency. For example, Hispanics have twice the tendency of non-Hispanics to have visited El Pollo Loco or Rio Bravo Cantina in the past 30 days, and a 20 percent higher tendency to visit Taco Bell and Don Pablo's. Hispanics also have elevated tendencies to visit a number of burger and pizza restaurants. The results in tables 2 and 3 suggest that black and white restaurant preferences are more different than Hispanic and non-Hispanic preferences.

\section{c. Income/Education}

The Scarborough data report income only for a subset but education for the entire sample. Given the strong relationship between income and education, we examine restaurant patronage by whether people have completed college. Three things emerge from examination of tables 2 and 3. First, college educated persons patronize coffee and

\footnotetext{
${ }^{9}$ Note, however, that our argument does not require preferences to differ because of race. Rather, we are simply classifying people into "blacks" and "whites" as two groups with different preferences.

${ }^{10}$ This information is available at http://www.census.gov/prod/2001 pubs/c2kbr01-3.pdf (accessed September 1, 2004).
} 
bagel restaurants far more than their less educated counterparts (roughly double for Bruegger's Bagels, Einstein Bros. Bagels, Noah Bagel, and Starbuck's Coffee). Second, the college educated are also less likely to patronize chicken restaurants (see Church's, Lee's Famous, KFC). Third, college educated persons are more likely to patronize more expensive sitdown restaurants among the sitdown establishments that Consumer Reports (2003) classifies by price range. College educated persons have roughly double the tendency of less educated persons to patronize the two most expensive chains in the sample, Houston's and Ruth's Chris. By contrast, the college educated are relatively less likely to patronize Denny's and IHOP.

\section{What is the relevant market?}

Restaurants' products are generally consumed where they are produced, so location matters more than with more easily tradable goods. It is not immediately obvious what unit of geography corresponds to the market area for restaurants. At one extreme, it seems unlikely that consumers patronize restaurants beyond their metropolitan areas, or - similarly - their 3-digit zips.

Different types of restaurants surely have different-sized market areas, however.

A "fancy" downtown restaurant patronized on special occasions presumably draws customers from throughout a metro area. Fast food restaurants likely have smaller market areas. Most markets have multiple McDonald's restaurants, for example. Except when traveling about their metro areas, residents are unlikely to travel beyond their nearest McDonald's to patronize a different McDonald's. The relevant market size - and the correct geographic unit of analysis - is different for different types of restaurants. 
Rather than attempt to resolve this question a priori, we will empirically explore the appropriate level of geographic aggregation.

If demand for geographic areas' restaurants were drawn from within the respective geographic areas, then we would expect a strong relationship between geographic area demand (measured, say, by population) and geographic area entry (the number of restaurant establishments operating, $N$ ). Indeed, a relationship between $N$ and population at some level of geographic aggregation indicates that supply for that area serves demand at - or within - that level. We can draw some inferences about the relevant geographic market by examining the relationship between $N$ and population at successively less aggr egated levels of geography (3, 4, and 5-digit zips)

We begin with the relationship between market size (measured by population) and the number of restaurant establishments operating $(N)$. The first column of table 4 reports a regression of $N$ on population at the 3-digit zip level across the 684 metro area 3-digit zips. A 3-digit zip with an additional 1000 persons has 1.51 more restaurants. Three digit zips average about 1000 square miles of overall land and water area. If they were circular, they would have mean radius of 15.1 miles. It seems likely that restaurants in a 3-digit zip draw their customers from within the area.

The remaining columns revisit the entry-population relationship at progressively finer levels of geographic disaggregation. Column (2) shows that a 4-digit zip with an additional 1000 persons has 1.55 more restaurants. Four-digit zips average 178 square miles, with a (hypothetically circular) radius of 6.2 miles. The same entry-population relationship that holds for areas comprising hundreds of square miles also holds for these areas. Finally, column (3) shows a similarly strong - but slightly muted - relationship 
between entry and population at the 5-digit zip level. These areas have mean area of 47 miles, with an implied radius of 3 miles.

Regardless of the level of geography analyzed, an additional 1000 persons raises the number of restaurants in the area by between 1.4 and 1.6. One should note that this relationship does not need to hold. Given consumers' ability to travel, restaurants' location could be decoupled from population. Yet, the relationship between market size that holds for metro areas also holds for much narrower units of geography. While it surely true that consumers travel outside their zipcodes to obtain restaurant food, it appears that zipcodes' exports and imports roughly balance each other. To say this another way, the number of restaurants near a consumer is very sensitive to the number of persons nearby. This suggests that zipcode level analysis will be appropriate.

We can examine the relationship between restaurant availability and local and distant population more directly by simply including both local (5-digit zip) and more distant population terms in the regressions directly. In particular, we include a term for the population of the remainder of the 4-digit zip, as well as a term for the remainder of the 3-digit zip (see column 4 of table 4). Local 5-digit zip population has a slightly smaller coefficient than in column (3) of table 4, and the population of the remainder of the 4-digit zipcode has a significant but small coefficient (one fortieth of the immediate zip coefficient). Population of the remainder of the 3-digit zip has a negative and significant, but small, coefficient. The results indicate that the empirical measure of demand relevant to restaurant entry in a 5-digit zipcode is overwhelmingly local (within the immediate 5-digit zipcode). 
Existing entry studies tend to choose industries to make the choice of geography straightforward. For example, Bresnahan and Reiss examine small businesses (for example, tire dealers and dentists) in small, geographically isolated markets. A typical geographic area included in their studies had one or two firms. In markets the size of those they include, customers would be willing to patronize a firm anywhere in the market area, so all local population was relevant to the determination of market size. Berry and Waldfogel (1999) study radio markets. Since radio signals travel costlessly throughout metropolitan areas, the entire metro area is the obvious market to employ. Mazzeo (2002) examines entry into the hotel market, and his observations are exits off interstate highways, where except for the quality differentiation that is the focus of his study, hotels at the same exit are clearly in the same market.

Seim's (2003) study has a slightly more complicated situation which bears more comparison to ours. Seim studies the location of video rental outlets, and in order to study spatial issues, she makes census tracts her unit of observation. Her tracts have an average of 4400 persons and less than one video rental outlet, while the metropolitan areas overall have an average of 74,000 persons and 19 establishments. Roughly speaking, this suggests that an outlet needs nearly 4000 persons as potential customers. Because the census tracts typically have too few to support a store, one must view demand as deriving from both own-tract and nearby-tract population.

Our context differs in two respects. First, the average amount of population per restaurant across markets in our sample is under 1000. Our data are at the zipcode level, and the median MSA zipcode in the sample has population of 10,000, far above the average amount of population apparently needed to support a restaurant. Accordingly, 
the median zipcode has 12 restaurants. The density of restaurants makes it less clear that population outside the immediate area will be an important determinant of restaurant location.

\section{Population Mix and Product Availability: If You Come, they Will Build it}

Places with more people have more restaurants. But do all sorts of people bring forth additional restaurants to a similar extent? Table 5 revisits the regressions in table 4, replacing population with separate terms for black and non-black ("white"), Hispanic and non-Hispanic, and college-educated and non-college-educated population. The regressions clearly show that different population groups bear different relationships to restaurant availability. Black, Hispanics, and those without college education have smaller coefficients than non-blacks, non-Hispanics, and college educated persons, respectively. For example, the more blacks, Hispanics, or non-college graduates there are nearby, holding total population constant, the fewer restaurants nearby.

On its face this result seems to suggest that the product market mechanism that is the subject of this paper reinforces the other difficulties associated with residential segregation. For example, in addition to all of the other pathologies experienced by blacks in heavily black neighborhoods, individuals also face fewer product options in the restaurant market.

Our chain data allow us to observe the number of locations of each of 136 chains in each zipcode. Thus we can ask how, for example, the number of McDonald's locations varies across zipcodes with local black and white population. Given what we know about groups' preferences over restaurant food, we can ask whether restaurant 
markets reinforce agglomeration of like types by asking whether there are more restaurants that appeal to particular groups where those groups are more prevalent. What would we see if this view were correct? Recalling tables 2 and 3, we have reason to expect that educated consumers prefer high-price and coffee/bagel outlets, black consumers prefer restaurants offering Southern fare, and (perhaps to a lesser extent) Hispanics prefer Mexican food. We could analyze zipcode entry patterns for particular chains preferred by a group by asking, for example, whether Starbucks outlets are more likely to be available in zips with more college graduates.

Studying entry one chain at a time ignores strategic interaction. Whether McDonald's wants to operate in a zipcode surely depends on whether a chain offering close substitutes, say Burger King, also operates there. Hence, chain-by-chain entry models mischaracterize the relationship between population and entry. As one aggregates from the chain to the category, say from KFC to all fried chicken chains, then if the category includes all relevant substitutes, the shortcomings of ignoring strategic interactions will decline.

With these issues in mind, Table 6 reports regressions of this sort a few major chains (McDonald', Burger King, Taco Bell, Dunkin Donuts) as well as three others (KFC, Popeye's, and Starbuck's) preferred by different groups. The table includes estimates from 21 separate equations relating a particular chain's presence in a 5-digit zip to, say, black and white population or, separately, Hispanic and non-Hispanic population, or, finally, to college and non-college educated population. Probability derivatives from probit models are reported in the table. 
The results on chain entry reflect our data on preferences. While most black coefficients are smaller than the white coefficients, the black KFC and Popeye's coefficients are larger. None of the chains in this table has an Hispanic coefficient that exceeds its non-Hispanic coefficient. Except Starbucks, and to a less extent Dunkin Donuts, all of the chains have smaller college than non-college coefficients. Indeed, many coefficients are negative and significant: 5-digit zips with more college graduates, holding the non-college graduate population constant, are less likely to have a McDonald's, a Burger King, or a Taco Bell present. In interpreting these coefficients it is, again, important to recognize the one-at-a-time nature of the table 6 exercise. College educated persons do not literally reduce the profitability of, say, a McDonalds outlet. Rather, 5-digit zips with more college-educated persons attract other entry that makes McDonald's entry less likely.

Aggregating particular chains into groups avoids some of the table 6 problems. Table 7 asks how entry of particular types of restaurants varies across 5-digit zips with black and white population. The first three columns are OLS regressions with the numbers of sample chains, sample sitdown chains, and sample fast food chains as dependent variables. Because the remaining columns are based on narrower categories, we estimate them as probits (with probability derivatives reported in the table). As with restaurants overall (see table 5), places with more whites have more sample chains, especially in the sitdown category. Places with more whites also have higher probabilities of sitdown restaurants in all three Consumer Reports price ranges (see columns 3-6). 
The sample chain cuisine breakdown, in columns (7) - (11), indicates that places with more whites are more likely to have a pizza, Mexican, and especially a coffee/bagel restaurant. Coefficients are nearly equal across race for the presence of a burger restaurant. Finally, places with more blacks, holding total population constant, are more likely to have a sample chicken chain present. Overall, 31 percent of sample zipcodes have a sample chicken chain restaurant. By contrast, nearly 60 percent of the 811 zipcodes that are over half black have a sample chicken chain. ${ }^{11}$

Tables 8-10 repeat the exercise of table 7 by Hispanic status, college education, and income (whether household income exceeds $\$ 40,000$ per year). Patterns for Hispanics are similar to those for blacks, except that the non-Hispanic coefficient exceeds the Hispanic coefficient for all of the particular sample chain cuisines.

In table 9 the non-college coefficient exceeds the college coefficient for all restaurant categories, except for the two more expensive groups based on Consumer Reports price classifications and the coffee/bagel chains. Overall, 28 percent of sample zipcodes have a coffee/bagel chain. Over half of the 978 heavily educated (over 36 percent of adults college educated) have a coffee/bagel chain from the sample. ${ }^{12}$ In table 10 the higher-income coefficient exceeds the lower-income coefficient for all restaurant groups except sample chicken and burger chains.

\footnotetext{
${ }^{11}$ Similar patterns hold across four-digit zipcodes: 53 percent of sample four-digit zipcodes have a sample chicken chain; 70 percent of the heavily black (over a third black) four-digit zipcodes have a sample chicken chain.

${ }^{12}$ Similar patterns hold for four-digit zipcodes: 44 percent of sample four-digit zipcodes have a sample coffee/bagel chain, while 71 percent of the heavily (over a third) college educated four-digit zipcodes have a sample coffee/bagel chain.
} 
The results in tables 7-10 clearly show that the mix of restaurants available in a zip code is sensitive to the mix of consumers. Places with more members of a group preferring a particular cuisine are more likely to be served by a restaurant in that cuisine.

\section{Conclusions and Implications}

What have we shown? We have documented that agglomeration of demographically similar persons brings forth private products - in this case, restaurants preferred by the agglomerating group. Given the evidence we present on how preferences vary by group, this suggests welfare benefits of like-agglomeration, provided that people value proximity to their preferred restaurants.

Residential location and sorting is a topic generally thought to be in the purview of public and urban economics. The entire literature on Tiebout (1956) sorting is focused on choice of jurisdiction based on the nature of government-provided goods. I do not dispute the importance of these goods and services, but I argue here that goods provided in private markets provide another important amenity for potential residents to consider when choosing communities.

The theoretical idea advanced in this research - that with substantial fixed costs and heterogenous consumers, one's welfare depends on the distribution of consumer types - is straightforward, even uncontroversial. The only question has been whether the mechanism is important or even detectable. The industries where it has been previously documented are unusual in the size of their fixed costs. Yet, the restaurant industry, with an establishment per 1000 people, has low fixed costs. What is remarkable here is that the mechanism operates in an industry with low fixed costs. 
Like local public goods, the private production of local private goods also entails fixed costs, which makes their provision lumpy and sensitive to the distribution of preferences. The median voter holds a celebrated place in economists' thinking about residential sorting and the provision of local public goods. For some sorts of goods restaurants may be a prime example - the median customer may be a useful metaphor.

That agglomeration brings about a benefit to persons, in their capacity as restaurant patrons, says nothing about whether this mechanism causes, or even contributes to, the agglomeration of like individuals. And, indeed, it is hard to believe that the pull of appealing restaurants weighs heavily against, say schools, parks, housing, or public safety in neighborhood choice. Still, the fact that the availability of products privately provided under conditions of increasing costs in some industry is at least suggestive that this mechanism might operate in other industries as well. Retailing and the provision of worship services come to mind as other venues where these mechanisms might operate. The usual call for more research is warranted. 


\section{References}

Bayer, Patrick, Robert McMillan, and Kim Reuben. "An Equilibrium Model of Sorting in an Urban Housing Market.” Mimeo. Yale University. Oct. 2002.

Berry, Steven T. "Estimation of a Model of Entry in the Airline Industry." Econometrica, vol. 60, no. 4, July 1992, pp. 889-917.

Berry, Steven T; Waldfogel, Joel. "Free Entry and Social Inefficiency in Radio Broadcasting." Rand Journal of Economics. Vol. 30 (3). p 397-420. Autumn 1999a.

Berry, Steven T; Waldfogel, Joel. "Product Quality and Market Size.” NBER Working paper 9675, May 2003.

Bresnahan, Timothy F; Reiss, Peter C. "Entry and Competition in Concentrated Markets.” Journal of Political Economy. Vol. 99 (5). p 977-1009. October 1991.

Bresnahan, Timothy F; Reiss, Peter C. "Entry in Monopoly Markets." The Review of Economic Studies. Vol. 57 (4). p 531-53. October 1990.

Christaller, Walter. Central Places in Southern Germany. Englewood Cliffs, NJ: Prentice Hall. 1966.

Consumer Reports. "Chain Restaurants: Best Meals. Best Deals." Consumer Reports. July 2003. pp. 18-23.

Council of Economic Advisers. Economic Report of the President, 2004.

Cutler, David M. and Edward L. Glaeser. “Are Ghettos Good or Bad?” Quarterly Journal of Economics, vol. 112, no. 3, August 1997, pp. 827-72.

Cutler, David M, Edward L. Glaeser, and Jacob L. Vigdor. "The Rise and Decline of the American Ghetto.” Journal of Political Economy, vol. 107, no. 3, June 1999, pp. 455-506.

Eaton, B. Curtis and Richard G. Lipsey. "An Economic Theory of Central Places." The Economic Journal, vol. 92, no. 365 (March 1982): 56-72.

Epple, Dennis and Holger Sieg. "Estimating Equilibrium Models of Local Jurisdictions." Journal of Political Economy, vol. 107, no. 4, August 1999, pp. 645-81.

Dixit, Avinash K; Stiglitz, Joseph E. "Monopolistic Competition and Optimum Product Diversity." American Economic Review. Vol. 67 (3). p 297-308. June 1977.

Friedman, Milton. Capitalism and Freedom. Chicago: University of Chicago Press, 1962 
George, Lisa and Joel Waldfogel. "Who Affects Whom in Daily Newspaper Markets?" Journal of Political Economy, vol. 111, no. 4, August 2003, pp. 765-84.

Glaeser, Edward L. Jed Kolko, and Albert Saiz. "Consumer City.” Journal of Economic Geography, vol. 1, no. 1, January 2001, pp. 27-50

Gyourko, Joseph and Joseph Tracy. "The Structure of Local Public Finance and the Quality of Life.” Journal of Political Economy, vol. 99, no. 4, August 1991, pp. 774-806.

Hotelling, Harold. "Stability in Competition." The Economic Journal, Vol. 39, No. 153. (Mar., 1929), pp. 41-57.

Holmes, Thomas. "How Important Is Variety and Returns to Scale; What Can We Learn from Local Demand?” Mimeo, University of Minnesota, December 1998.

Massey, Douglas S. and Nancy A. Denton. American apartheid : segregation and the making of the underclass. Cambridge, Mass.: Harvard University Press, 1993.

Mazzeo, Michael. "Product Choice and Oligopoly Market Structure." RAND Journal of Economics 33 (Summer 2002):1-22.

Mill, John Stuart. On Liberty. Indianapolis: Hacket Publishing Company, 1978.

Prescott, Edward C; Visscher, Michael. "Sequential Location among Firms with Foresight." The Bell Journal of Economics. Vol. 8 (2). p 378-93. Autumn. 1977.

Seim, Katja. "An Empirical Model of Firm Entry with Endogenous Product-Type Choices." Feb. 2004.

http://faculty-gsb.stanford.edu/seim/personal_page/Documents/entry_types.pdf

Sinai, Todd and Joel Waldfogel. "Geography and the Internet: Is the Internet a Substitute or a Complement for Cities?" Journal of Urban Economics. 2004.

Spence, Michael. "Product Selection, Fixed Costs, and Monopolistic Competition." The Review of Economic Studies. Vol. 43 (2). p 217-35. June 1976.

Spence, Michael. "Product Differentiation and Welfare." American Economic Review. Vol. 66 (2). p 407-14. May 1976.

Sutton, John. Sunk costs and market structure: Price competition, advertising, and the evolution of concentration.. Cambridge, Mass. and London: MIT Press. 1991.

Tiebout, Charles. "A Pure Theory of Local Expenditures." The Journal of Political Economy. V. 64(5) (Oct 1956) pp. 416-424. 
Waldfogel, Joel. "Preference Externalities: An Empirical Study of Who Benefits Whom in Differentiated-Product Markets." RAND Journal of Economics, vol. 34, no. 3, Autumn 2003, pp. 557-68.

Waldfogel, Joel. "Who Benefits Whom in Local Television Markets?" Brookings Wharton Papers on Urban Economics, 2004. 
Table 1a: Population, Restaurants, and Demographic Mix, by Level of Geographic Aggregation

\begin{tabular}{|c|c|c|c|c|c|}
\hline$\underline{\text { 5-digit zips }}$ & mean & median & $75^{\text {th }}$ & $90^{\text {th }}$ & $\mathrm{N}$ \\
\hline Restaurants & 24.9 & 12 & 38 & 68 & 14954 \\
\hline population & 15,450 & 9,965 & 24,269 & 37,919 & 14954 \\
\hline$\%$ black & 9.5 & 2.1 & 9.4 & 28.8 & 14903 \\
\hline$\%$ Hispanic & 9.8 & 2.7 & 8.8 & 27.5 & 14903 \\
\hline$\%$ college & 17.7 & 15.9 & 24.0 & 32.3 & 14764 \\
\hline$\%$ inc $>40 \mathrm{k}$ & 54.7 & 54.8 & 67.3 & 77.2 & 14716 \\
\hline Sq. miles & 47.2 & 18.0 & 48.2 & 100.6 & 14931 \\
\hline radius & 2.95 & 2.40 & 3.92 & 5.66 & 14931 \\
\hline 4-digit zips & mean & median & $75^{\text {th }}$ & $90^{\text {th }}$ & $\mathrm{N}$ \\
\hline Restaurants & 94.1 & 41 & 127 & 256 & 3960 \\
\hline population & 58,344 & 30,772 & 79,677 & 150,671 & 3960 \\
\hline$\%$ black & 8.4 & 2.8 & 10.5 & 24.7 & 3945 \\
\hline$\%$ Hispanic & 8.8 & 2.6 & 8.4 & 24.4 & 3945 \\
\hline$\%$ college & 17.9 & 16.7 & 22.7 & 28.9 & 3931 \\
\hline$\%$ inc $>40 \mathrm{k}$ & 54.8 & 54.4 & 64.6 & 73.0 & 3923 \\
\hline Sq. miles & 177.8 & 99.5 & 194.6 & 329.1 & 3960 \\
\hline radius & 6.23 & 5.63 & 7.87 & 10.23 & 3960 \\
\hline 3-digit zips & mean & median & $75^{\text {th }}$ & $90^{\text {th }}$ & $\mathrm{N}$ \\
\hline Restaurants & 545.0 & 335 & 676 & 1259 & 684 \\
\hline population & 337,800 & 204,100 & 421,200 & 782,900 & 684 \\
\hline$\%$ black & 10.5 & 5.9 & 15.4 & 28.2 & 684 \\
\hline$\%$ Hispanic & 9.7 & 3.9 & 10.9 & 27.3 & 684 \\
\hline$\%$ college & 19.1 & 18.3 & 22.4 & 26.9 & 684 \\
\hline$\%$ inc $>40 \mathrm{k}$ & 52.8 & 51.2 & 60.1 & 67.9 & 684 \\
\hline Sq. miles & 1029.3 & 624.2 & 1224.0 & 2002.7 & 684 \\
\hline radius & 15.1 & 14.1 & 19.7 & 25.2 & 684 \\
\hline
\end{tabular}


Table 1b: Sample Chain Restaurants, by Cuisine and Level of Geographic Aggregation

\begin{tabular}{ccccccc}
\hline & & & & & & \\
& 5-digit zip & & 4-digit zip & \multicolumn{3}{c}{ zip } \\
\hline & Number & Presence & Number & Presence & Number & Presence \\
\hline Restaurants & 24.93 & $87.95 \%$ & 94.14 & $93.96 \%$ & 545.05 & $98.98 \%$ \\
Sample Chains & 7.19 & $64.14 \%$ & 27.15 & $80.28 \%$ & 157.16 & $95.91 \%$ \\
Fast Food & 5.65 & $63.32 \%$ & 21.35 & $79.65 \%$ & 123.60 & $95.91 \%$ \\
Sitdown & 1.54 & $40.60 \%$ & 5.80 & $63.23 \%$ & 33.56 & $92.84 \%$ \\
Chicken & 0.54 & $31.12 \%$ & 2.04 & $53.03 \%$ & 11.79 & $89.77 \%$ \\
Pizza & 1.02 & $41.75 \%$ & 3.88 & $64.17 \%$ & 22.48 & $93.27 \%$ \\
Burger & 1.89 & $52.93 \%$ & 7.15 & $72.22 \%$ & 41.41 & $93.57 \%$ \\
Mexican & 0.39 & $26.09 \%$ & 1.49 & $48.86 \%$ & 8.62 & $86.70 \%$ \\
$\quad$ Steak & 0.16 & $10.81 \%$ & 0.61 & $28.26 \%$ & 3.52 & $73.25 \%$ \\
$\quad$ Coffee,Bagel & 0.57 & $27.54 \%$ & 2.15 & $43.59 \%$ & 12.46 & $73.25 \%$ \\
$\mathrm{~N}$ & & & & & & \\
\hline
\end{tabular}


Table 2: Tendency to Patronize Selected Fast Food Chain Restaurants

\begin{tabular}{|c|c|c|c|c|c|c|c|c|c|c|c|}
\hline \multirow{2}{*}{ Cuisine } & \multicolumn{4}{|c|}{$\begin{array}{c}\text { Visit in last } 30 \\
\text { days }\end{array}$} & \multicolumn{2}{|c|}{ Visit in last 30 days } & \multicolumn{4}{|c|}{ Visit in last 30 days } & \multirow[b]{2}{*}{$\begin{array}{l}\text { markets } \\
\text { present }\end{array}$} \\
\hline & chain & $\begin{array}{l}\text { non- } \\
\text { black }\end{array}$ & black & black/non & Non_Hisp & Hispanic & hisp/non & No College & College & coll/nocoll & \\
\hline & Arbys & $22.1 \%$ & $18.5 \%$ & 0.83 & $21.9 \%$ & $20.4 \%$ & 0.93 & $21.8 \%$ & $21.3 \%$ & 0.98 & 65 \\
\hline Chicken & Boston mkt & $8.2 \%$ & $9.6 \%$ & 1.16 & $8.5 \%$ & $9.1 \%$ & 1.07 & $7.5 \%$ & $10.2 \%$ & 1.37 & 50 \\
\hline Coffee/bagel & Brueggers & $10.9 \%$ & $11.7 \%$ & 1.08 & $10.8 \%$ & $10.7 \%$ & 0.98 & $7.8 \%$ & $16.2 \%$ & 2.09 & 9 \\
\hline \multirow[t]{2}{*}{ Burger } & Burger King & $44.2 \%$ & $52.1 \%$ & 1.18 & $44.2 \%$ & $53.4 \%$ & 1.21 & $46.7 \%$ & $41.9 \%$ & 0.90 & 66 \\
\hline & Captain D's Seafood & $14.9 \%$ & $22.7 \%$ & 1.52 & $16.4 \%$ & $16.9 \%$ & 1.03 & $18.0 \%$ & $12.7 \%$ & 0.71 & 17 \\
\hline Coffee/bagel & Caribou Coffee & $4.8 \%$ & $4.4 \%$ & 0.92 & $4.6 \%$ & $4.1 \%$ & 0.89 & $2.7 \%$ & $7.6 \%$ & 2.77 & 7 \\
\hline Burger & Checkers & $9.7 \%$ & $20.7 \%$ & 2.14 & $10.9 \%$ & $17.0 \%$ & 1.56 & $12.1 \%$ & $9.4 \%$ & 0.77 & 10 \\
\hline Chicken & Chick-Fil-A & $12.9 \%$ & $14.7 \%$ & 1.14 & $12.8 \%$ & $14.4 \%$ & 1.12 & $12.1 \%$ & $15.0 \%$ & 1.24 & 42 \\
\hline Chicken & $\begin{array}{l}\text { Church's Fried } \\
\text { Chicken }\end{array}$ & $4.9 \%$ & $22.7 \%$ & 4.64 & $6.8 \%$ & $10.4 \%$ & 1.54 & $8.4 \%$ & $5.2 \%$ & 0.62 & 39 \\
\hline \multirow[t]{2}{*}{ Pizza } & Cici’s Pizza & $12.7 \%$ & $12.2 \%$ & 0.97 & $11.3 \%$ & $18.1 \%$ & 1.61 & $12.8 \%$ & $11.5 \%$ & 0.90 & 7 \\
\hline & Dairy Queen & $16.3 \%$ & $14.2 \%$ & 0.87 & $16.2 \%$ & $16.1 \%$ & 1.00 & $14.5 \%$ & $14.0 \%$ & 0.97 & 60 \\
\hline Pizza & Dominos & $11.8 \%$ & $15.3 \%$ & 1.30 & $11.5 \%$ & $17.8 \%$ & 1.55 & $12.6 \%$ & $11.2 \%$ & 0.89 & 66 \\
\hline Coffee/bagel & Einstein & $6.2 \%$ & $4.9 \%$ & 0.79 & $6.3 \%$ & $5.3 \%$ & 0.83 & $4.5 \%$ & $9.2 \%$ & 2.06 & 22 \\
\hline Mexican & El Pollo Loco & $11.0 \%$ & $12.3 \%$ & 1.12 & $8.9 \%$ & $17.7 \%$ & 1.99 & $11.3 \%$ & $10.5 \%$ & 0.92 & 5 \\
\hline burger & Hardee's & $19.0 \%$ & $18.6 \%$ & 0.98 & $19.0 \%$ & $18.0 \%$ & 0.95 & $20.6 \%$ & $15.4 \%$ & 0.75 & 32 \\
\hline Chicken & KFC & $22.8 \%$ & $38.9 \%$ & 1.71 & $24.4 \%$ & $26.7 \%$ & 1.09 & $26.3 \%$ & $21.5 \%$ & 0.82 & 66 \\
\hline Burger & Krystal & $19.0 \%$ & $28.6 \%$ & 1.51 & $20.5 \%$ & $24.5 \%$ & 1.20 & $22.7 \%$ & $16.0 \%$ & 0.70 & 6 \\
\hline Chicken & Lees Famous & $11.8 \%$ & $20.7 \%$ & 1.75 & $12.8 \%$ & $15.2 \%$ & 1.19 & $14.1 \%$ & $9.7 \%$ & 0.69 & 6 \\
\hline Pizza & Lil Caesar & $5.5 \%$ & $7.6 \%$ & 1.38 & $5.3 \%$ & $8.7 \%$ & 1.64 & $6.0 \%$ & $4.8 \%$ & 0.80 & 64 \\
\hline \multirow{3}{*}{ Burger } & Long John Silver & $10.3 \%$ & $14.2 \%$ & 1.38 & $10.5 \%$ & $11.9 \%$ & 1.13 & $11.9 \%$ & $8.1 \%$ & 0.68 & 52 \\
\hline & McDonalds & $53.4 \%$ & $60.1 \%$ & 1.13 & $53.4 \%$ & $61.1 \%$ & 1.14 & $54.9 \%$ & $52.8 \%$ & 0.96 & 66 \\
\hline & Miami sub & $7.8 \%$ & $13.1 \%$ & 1.68 & $8.6 \%$ & $11.0 \%$ & 1.28 & $8.7 \%$ & $8.2 \%$ & 0.94 & 5 \\
\hline Chicken & Mrs Winner's & $8.2 \%$ & $20.1 \%$ & 2.44 & $10.8 \%$ & $11.1 \%$ & 1.03 & $11.6 \%$ & $9.5 \%$ & 0.82 & 5 \\
\hline Coffee/bagel & Noah bagel & $6.5 \%$ & $7.3 \%$ & 1.11 & $7.1 \%$ & $4.3 \%$ & 0.60 & $4.9 \%$ & $9.0 \%$ & 1.82 & 3 \\
\hline
\end{tabular}




\begin{tabular}{|c|c|c|c|c|c|c|c|c|c|c|c|}
\hline Pizza & Papa John & $13.7 \%$ & $13.9 \%$ & 1.02 & $13.5 \%$ & $16.3 \%$ & 1.20 & $13.0 \%$ & $15.0 \%$ & 1.15 & 55 \\
\hline Pizza & Peter Piper & $5.9 \%$ & $10.1 \%$ & 1.70 & $3.7 \%$ & $14.4 \%$ & 3.93 & $7.3 \%$ & $3.7 \%$ & 0.51 & 5 \\
\hline \multirow[t]{2}{*}{ chicken } & Popeye's & $10.4 \%$ & $30.3 \%$ & 2.93 & $13.1 \%$ & $19.6 \%$ & 1.50 & $14.6 \%$ & $11.7 \%$ & 0.80 & 20 \\
\hline & Quiznos & $4.9 \%$ & $4.4 \%$ & 0.90 & $4.8 \%$ & $4.8 \%$ & 1.01 & $3.9 \%$ & $6.1 \%$ & 1.55 & 7 \\
\hline Burger & Rallys & $11.0 \%$ & $24.1 \%$ & 2.20 & $12.7 \%$ & $16.0 \%$ & 1.26 & $14.0 \%$ & $10.4 \%$ & 0.74 & 18 \\
\hline \multirow[t]{2}{*}{ Coffee/bagel } & Starbucks & $7.5 \%$ & $6.0 \%$ & 0.81 & $7.4 \%$ & $8.1 \%$ & 1.10 & $5.5 \%$ & $10.6 \%$ & 1.94 & 59 \\
\hline & Subway & $22.7 \%$ & $24.5 \%$ & 1.08 & $22.9 \%$ & $24.9 \%$ & 1.09 & $22.4 \%$ & $24.3 \%$ & 1.09 & 66 \\
\hline Mexican & Taco Bell & $32.8 \%$ & $35.1 \%$ & 1.07 & $32.7 \%$ & $38.8 \%$ & 1.19 & $4.3 \%$ & $5.6 \%$ & 1.31 & 65 \\
\hline Burger & Wendys & $32.0 \%$ & $35.9 \%$ & 1.12 & $32.4 \%$ & $33.8 \%$ & 1.04 & $32.2 \%$ & $33.0 \%$ & 1.02 & 66 \\
\hline Burger & White Castle & $18.7 \%$ & $35.1 \%$ & 1.87 & $20.8 \%$ & $21.4 \%$ & 1.03 & $23.1 \%$ & $16.0 \%$ & 0.69 & 9 \\
\hline
\end{tabular}


Table 3: Tendency to Patronize Selected Sit Down Chain Restaurants

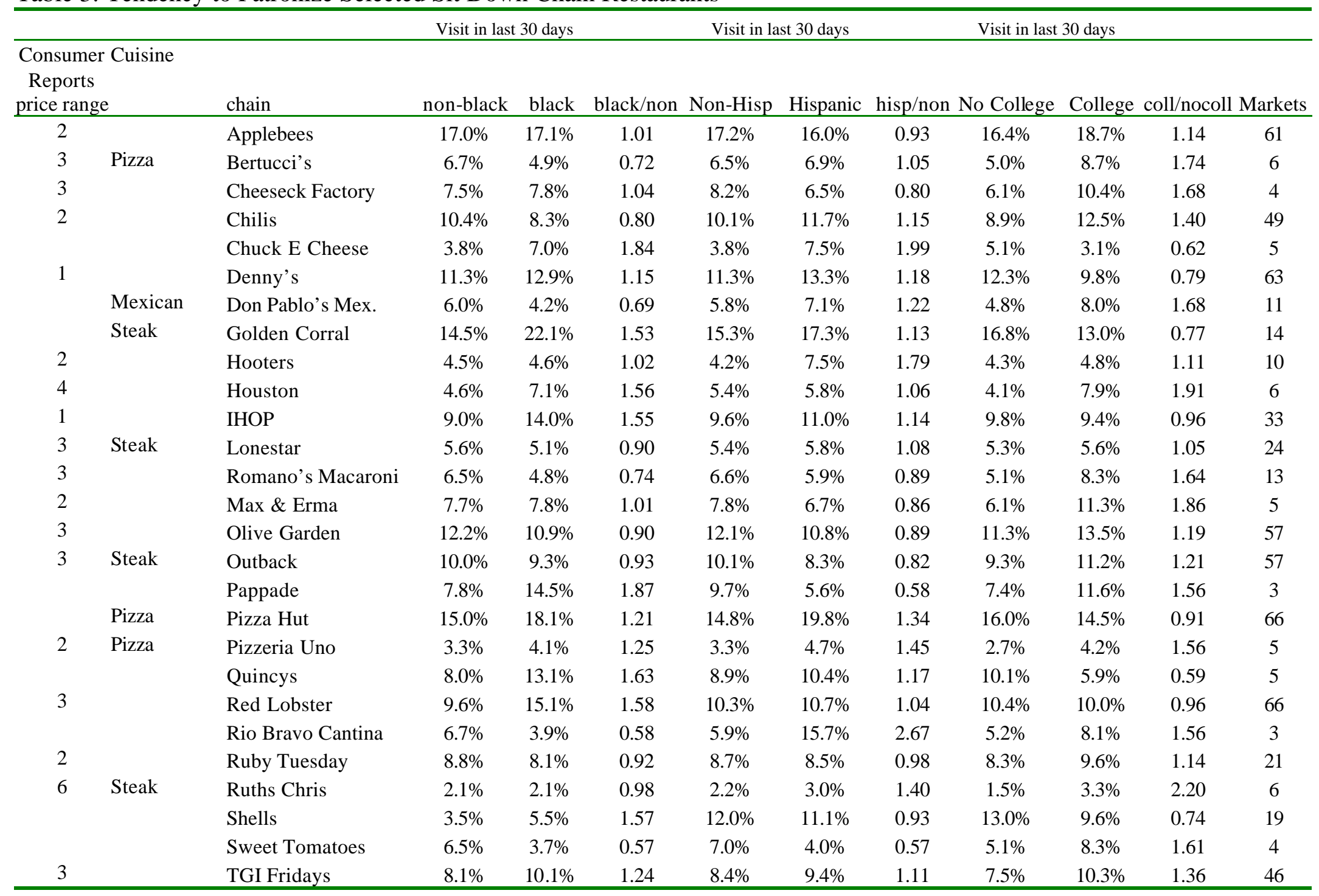




\begin{tabular}{llllllllllll}
\hline 3 & Tony Roma & $4.0 \%$ & $6.1 \%$ & 1.51 & $4.4 \%$ & $3.7 \%$ & 0.83 & $4.0 \%$ & $5.0 \%$ & 1.27 & 10 \\
\hline
\end{tabular}


Table 4: Restaurants and Population at Various Levels of Geography

\begin{tabular}{lcccc}
\hline & $(1)$ & $(2)$ & $(3)$ & $(4)$ \\
\hline & 3-digit zip & 4-digit zip & 5-digit zip & 5-digit zip \\
\hline Population (000) & 1.5053 & 1.5500 & 1.3869 & \\
& $(0.0307)^{* *}$ & $(0.0171)^{* *}$ & $(0.0125)^{* *}$ & \\
5-digit zip pop (000) & & & 1.3334 \\
& & & $(0.0146)^{* *}$ \\
Rest of 4-digit zip pop (000) & & & 0.0297 \\
& & & $0.0031)^{* *}$ \\
Rest of 3-digit zip pop (000) & & & -0.0027 \\
& & & & $(0.0005)^{* *}$ \\
Constant & 36.5925 & 3.7116 & 3.5030 & 3.3209 \\
& $(15.7039)^{*}$ & $(1.6138)^{*}$ & $(0.2787)^{* *}$ & $(0.3144)^{* *}$ \\
Observations & 684 & 3960 & 14954 & 14954 \\
R-squared & 0.78 & 0.68 & 0.45 & 0.45 \\
\hline Standard errors in parenthes. * & & &
\end{tabular}

Standard errors in parentheses. * significant at 5\%; ** significant at $1 \%$ 
Table 5: Restaurant Entry and Population Composition, Various Levels of Geographic Aggregation

\begin{tabular}{|c|c|c|c|c|c|c|c|c|c|}
\hline & $(1)$ & (2) & (3) & (4) & $(5)$ & $(6)$ & $(7)$ & $(8)$ & $(9)$ \\
\hline & 5-digit zip & 5-digit zip & 5-digit zip & 4-digit zip & 4-digit zip & 4-digit zip & 3-digit zip & 3-digit zip & 3-digit zip \\
\hline \multirow[t]{2}{*}{ White Pop (000) } & 1.5301 & & & 1.6656 & & & 1.5062 & & \\
\hline & $(0.0141)^{* *}$ & & & $(0.0235)^{* *}$ & & & $(0.0429)^{* *}$ & & \\
\hline \multirow[t]{2}{*}{ Black Pop (000) } & 0.6432 & & & 1.0949 & & & 1.5009 & & \\
\hline & $(0.0372)^{* *}$ & & & $(0.0663)^{* *}$ & & & $(0.1443)^{* *}$ & & \\
\hline \multirow[t]{2}{*}{ Non Hispanic Pop (000) } & & 1.6885 & & & 1.8977 & & & 1.8842 & \\
\hline & & $(0.0151)^{* *}$ & & & $(0.0215)^{* *}$ & & & $(0.0372)^{* *}$ & \\
\hline \multirow[t]{2}{*}{ Hisp. Pop (000) } & & 0.5819 & & & 0.5780 & & & 0.5784 & \\
\hline & & $(0.0271)^{* *}$ & & & $(0.0435)^{* *}$ & & & $(0.0684)^{* *}$ & \\
\hline \multirow[t]{2}{*}{ College Educ'd Pop (000) } & & & 2.5800 & & & 4.1417 & & & 4.6446 \\
\hline & & & $(0.0830)^{* *}$ & & & $(0.1566)^{* *}$ & & & $(0.3074)^{* *}$ \\
\hline \multirow[t]{2}{*}{ Non-coll. (000) } & & & 1.6854 & & & 1.4644 & & & 1.2353 \\
\hline & & & $(0.0288)^{* *}$ & & & $(0.0481)^{* *}$ & & & $(0.0926)^{* *}$ \\
\hline \multirow[t]{2}{*}{ Constant } & 3.0887 & 1.5824 & 1.7673 & 1.3379 & -4.2379 & -0.5201 & 36.5142 & -20.7481 & 17.3144 \\
\hline & $(0.2753)^{* *}$ & $(0.2752)^{* *}$ & $(0.2535)^{* *}$ & $(1.6382)$ & $(1.5434)^{* *}$ & (1.3141) & $(15.9129)^{*}$ & (14.2306) & (10.3865) \\
\hline Observations & 14954 & 14954 & 14931 & 3960 & 3960 & 3960 & 684 & 684 & 684 \\
\hline R-squared & 0.47 & 0.49 & 0.55 & 0.68 & 0.72 & 0.79 & 0.78 & 0.83 & 0.91 \\
\hline
\end{tabular}

Standard errors in parentheses. * significant at $5 \%$; ** significant at $1 \%$ 
Table 6: Chain Presence and Group Population in 5-Digit Zip

\begin{tabular}{|c|c|c|c|c|c|c|}
\hline & white & black & Non-Hisp & Hisp & College & Non-Coll \\
\hline \multirow[t]{2}{*}{ McDonalds } & 0.0252 & 0.0235 & 0.0337 & 0.0072 & -0.0258 & 0.0525 \\
\hline & $(0.0004)^{* *}$ & $(0.0011)^{* *}$ & $(0.0005)^{* *}$ & $(0.0007)^{* *}$ & $(0.0025)^{* *}$ & $(0.0010)^{* *}$ \\
\hline \multirow[t]{2}{*}{ Burger King } & 0.0159 & 0.0094 & 0.0183 & 0.0054 & -0.0147 & 0.0289 \\
\hline & $(0.0003)^{* *}$ & $(0.0006)^{* *}$ & $(0.0003)^{* *}$ & $(0.0005)^{* *}$ & $(0.0016)^{* *}$ & $(0.0006)^{* *}$ \\
\hline \multirow[t]{2}{*}{ Taco Bell } & 0.013 & 0.0057 & 0.0148 & 0.0038 & -0.0063 & 0.0211 \\
\hline & $(0.0002)^{* *}$ & $(0.0006)^{* *}$ & $(0.0003)^{* *}$ & $(0.0004)^{* *}$ & $(0.0013)^{* *}$ & $(0.0005)^{* *}$ \\
\hline \multirow[t]{2}{*}{$\mathrm{KFC}$} & 0.0126 & 0.0169 & 0.0161 & 0.0057 & -0.0202 & 0.0275 \\
\hline & $(0.0002)^{* *}$ & $(0.0007)^{* *}$ & $(0.0003)^{* *}$ & $(0.0004)^{* *}$ & $(0.0014)^{* *}$ & $(0.0006)^{* *}$ \\
\hline \multirow[t]{2}{*}{ Popeye's Fried Chicken } & 0.0023 & 0.0063 & 0.0035 & 0.0021 & -0.003 & 0.0057 \\
\hline & $(0.0001)^{* *}$ & $(0.0003)^{* *}$ & $(0.0001)^{* *}$ & $(0.0002)^{* *}$ & $(0.0006)^{* *}$ & $(0.0002) * *$ \\
\hline \multirow[t]{2}{*}{ Starbucks } & 0.0097 & -0.0037 & 0.0099 & 0.0024 & 0.0553 & -0.0005 \\
\hline & $(0.0002)^{* *}$ & $(0.0007)^{* *}$ & $(0.0002)^{* *}$ & $(0.0004)^{* *}$ & $(0.0016)^{* *}$ & -0.0004 \\
\hline \multirow[t]{2}{*}{ Dunkin Donuts } & 0.0048 & 0.0042 & 0.0062 & 0.0004 & 0.0067 & 0.0064 \\
\hline & $(0.0002)^{* *}$ & $(0.0004)^{* *}$ & $(0.0002)^{* *}$ & -0.0003 & $(0.0009)^{* *}$ & $(0.0003)^{* *}$ \\
\hline $\mathrm{N}$ & 14954 & & 14931 & & 14931 & \\
\hline
\end{tabular}

Notes: Probit estimates where each row reflects three separate equations, one

with black and white (non-black) population, another with Hisp and non-Hisp, etc. Probability derivatives reported. Population is measured in thousands. 
Table 7: Restaurant Targeting and Race Distribution

\begin{tabular}{|c|c|c|c|c|c|c|c|c|c|c|c|}
\hline & (1) & (2) & (3) & (4) & (5) & (6) & (7) & (8) & (9) & (10) & (11) \\
\hline & $\begin{array}{l}\text { \# Sample } \\
\text { Chains }\end{array}$ & $\begin{array}{l}\text { Sitdown } \\
\text { Chains }\end{array}$ & $\begin{array}{c}\text { Fast Food } \\
\text { Chains }\end{array}$ & CR \$ & CR \$ \$ & CR $\$ \$ \$+$ & Chicken & Pizza & Burger & Mexican & $\begin{array}{c}\text { Coffee, } \\
\text { bagel }\end{array}$ \\
\hline White $(000)$ & $\begin{array}{c}0.4624 \\
(0.0042)^{* *}\end{array}$ & $\begin{array}{c}0.1051 \\
(0.0015)^{* *}\end{array}$ & $\begin{array}{c}0.3573 \\
(0.0030)^{* *}\end{array}$ & $\begin{array}{c}0.0127 \\
(0.0002) * *\end{array}$ & $\begin{array}{c}0.0083 \\
(0.0002)^{* *}\end{array}$ & $\begin{array}{c}0.0061 \\
(0.0002)^{* *}\end{array}$ & $\begin{array}{c}0.0177 \\
(0.0003)^{* *}\end{array}$ & $\begin{array}{c}0.0290 \\
(0.0004) * *\end{array}$ & $\begin{array}{c}0.0302 \\
(0.0005)^{* *}\end{array}$ & $\begin{array}{c}0.0153 \\
(0.0003)^{* *}\end{array}$ & $\begin{array}{c}0.0152 \\
(0.0003)^{* * *}\end{array}$ \\
\hline Black (000) & $\begin{array}{c}0.2220 \\
(0.0112)^{* *}\end{array}$ & $\begin{array}{c}0.0190 \\
(0.0040)^{* *}\end{array}$ & $\begin{array}{c}0.2031 \\
(0.0080)^{* *}\end{array}$ & $\begin{array}{c}0.0033 \\
(0.0006)^{* *}\end{array}$ & $\begin{array}{c}0.0007 \\
(0.0005)\end{array}$ & $\begin{array}{c}0.0013 \\
(0.0004)^{* *}\end{array}$ & $\begin{array}{c}0.0340 \\
(0.0011)^{* *}\end{array}$ & $\begin{array}{c}0.0123 \\
(0.0009)^{* *}\end{array}$ & $\begin{array}{c}0.0285 \\
(0.0014)^{* * *}\end{array}$ & $\begin{array}{c}0.0053 \\
(0.0006)^{* *}\end{array}$ & $\begin{array}{c}0.0026 \\
(0.0007)^{* *}\end{array}$ \\
\hline Constant & $\begin{array}{c}0.5317 \\
(0.0828)^{* *}\end{array}$ & $\begin{array}{c}0.0861 \\
(0.0296)^{* *}\end{array}$ & $\begin{array}{c}0.4456 \\
(0.0593)^{* *}\end{array}$ & & & & & & & & \\
\hline $\begin{array}{l}\text { Observations } \\
\text { R-squared }\end{array}$ & $\begin{array}{c}14954 \\
0.47\end{array}$ & $\begin{array}{c}14954 \\
0.25\end{array}$ & $\begin{array}{c}14954 \\
0.52\end{array}$ & 14954 & 14954 & 14954 & 14954 & 14954 & 14954 & 14954 & 14954 \\
\hline
\end{tabular}

Notes: Standard errors in parentheses. * significant at 5\%; ** significant at 1\%. Columns (1)-(3) are OLS regressions. Remaining columns are probit estimates with probability derivatives reported. 
Table 8: Restaurant Targeting and Hispanic Status

\begin{tabular}{|c|c|c|c|c|c|c|c|c|c|c|c|}
\hline & (1) & (2) & (3) & (4) & (5) & (6) & (7) & (8) & (9) & (10) & (11) \\
\hline & $\begin{array}{l}\text { \# Sample } \\
\text { Chains }\end{array}$ & $\begin{array}{l}\text { Sitdown } \\
\text { Chains }\end{array}$ & $\begin{array}{l}\text { Fast Food } \\
\text { Chains }\end{array}$ & CR \$ & CR \$ \$ & CR $\$ \$ \$+$ & Chicken & Pizza & Burger & Mexican & $\begin{array}{c}\text { Coffee, } \\
\text { bagel }\end{array}$ \\
\hline \multirow{2}{*}{$\begin{array}{l}\text { Non-Hisp Pop. } \\
(000)\end{array}$} & 0.5323 & 0.1217 & 0.4106 & 0.0144 & 0.0100 & 0.0075 & 0.0236 & 0.0335 & 0.0423 & 0.0165 & 0.0169 \\
\hline & $(0.0045)^{* *}$ & $(0.0016)^{* *}$ & $(0.0032)^{* *}$ & $(0.0003)^{* *}$ & $(0.0002) * *$ & $(0.0002)^{* *}$ & $(0.0004) * *$ & $(0.0005)^{* *}$ & $(0.0006)^{* *}$ & $(0.0003)^{* *}$ & $(0.0003)^{* *}$ \\
\hline \multirow[t]{2}{*}{ Hispanic } & 0.1336 & 0.0097 & 0.1239 & 0.0027 & -0.0006 & -0.0010 & 0.0089 & 0.0082 & 0.0076 & 0.0059 & 0.0036 \\
\hline & $(0.0080)^{* *}$ & $(0.0029)^{* *}$ & $(0.0057)^{* *}$ & $(0.0004)^{* *}$ & $(0.0004)$ & $(0.0004)^{* *}$ & $(0.0005)^{* *}$ & $(0.0007)^{* *}$ & $(0.0007)^{* *}$ & $(0.0004)^{* *}$ & $(0.0005)^{* *}$ \\
\hline Constant & $\begin{array}{l}-0.0480 \\
(0.0812)\end{array}$ & $\begin{array}{c}-0.0682 \\
(0.0296)^{*}\end{array}$ & $\begin{array}{c}0.0201 \\
(0.0579)\end{array}$ & & & & & & & & \\
\hline Observations & 14954 & 14954 & 14954 & 14954 & 14954 & 14954 & 14954 & 14954 & 14954 & 14954 & 14954 \\
\hline R-squared & 0.51 & 0.28 & 0.56 & & & & & & & & \\
\hline
\end{tabular}

Notes: Standard errors in parentheses. * significant at 5\%; ** significant at 1\%. Columns (1)-(3) are OLS regressions. Remaining columns are probit estimates with probability derivatives reported. 
Table 9: Restaurant Targeting and Education Distribution

\begin{tabular}{|c|c|c|c|c|c|c|c|c|c|c|c|}
\hline & (1) & (2) & (3) & (4) & (5) & (6) & (7) & (8) & (9) & (10) & (11) \\
\hline & $\begin{array}{c}\text { \# Sample } \\
\text { Chains }\end{array}$ & $\begin{array}{c}\text { Sitdown } \\
\text { Chains }\end{array}$ & $\begin{array}{c}\text { Fast Food } \\
\text { Chains }\end{array}$ & CR \$ & CR \$ \$ & CR $\$ \$ \$+$ & Chicken & Pizza & Burger & Mexican & $\begin{array}{c}\text { Coffee, } \\
\text { bagel }\end{array}$ \\
\hline College Pop. & 0.2589 & 0.1159 & 0.1430 & 0.0038 & 0.0157 & 0.0157 & -0.0251 & 0.0129 & -0.0411 & -0.0049 & 0.0784 \\
\hline & $(0.0264)^{* *}$ & $(0.0096)^{* *}$ & $(0.0188)^{* *}$ & $(0.0013)^{* *}$ & $(0.0010)^{* *}$ & $(0.0009)^{* *}$ & $(0.0019)^{* *}$ & $(0.0027)^{* *}$ & $(0.0031)^{* *}$ & $(0.0014)^{* *}$ & $(0.0023)^{* *}$ \\
\hline Non-coll. & $\begin{array}{c}0.6354 \\
(0.0092)^{* *}\end{array}$ & $\begin{array}{c}0.1228 \\
(0.0033)^{* *}\end{array}$ & $\begin{array}{c}0.5126 \\
(0.0065)^{* *}\end{array}$ & $\begin{array}{c}0.0177 \\
(0.0005)^{* *}\end{array}$ & $\begin{array}{c}0.0079 \\
(0.0004)^{* *}\end{array}$ & $\begin{array}{c}0.0048 \\
(0.0003)^{* *}\end{array}$ & $\begin{array}{c}0.0401 \\
(0.0008)^{* *}\end{array}$ & $\begin{array}{c}0.0423 \\
(0.0009)^{* *}\end{array}$ & $\begin{array}{c}0.0702 \\
(0.0012)^{* *}\end{array}$ & $\begin{array}{c}0.0237 \\
(0.0006)^{* * *}\end{array}$ & $\begin{array}{c}0.0059 \\
(0.0006)^{* *}\end{array}$ \\
\hline Constant & $\begin{array}{c}0.3112 \\
(0.0806)^{* *}\end{array}$ & $\begin{array}{c}0.0347 \\
(0.0294)\end{array}$ & $\begin{array}{c}0.2765 \\
(0.0574)^{* *}\end{array}$ & & & & & & & & \\
\hline Observations & 14931 & 14931 & 14931 & 14931 & 14931 & 14931 & 14931 & 14931 & 14931 & 14931 & 14931 \\
\hline R-squared & 0.50 & 0.27 & 0.55 & & & & & & & & \\
\hline
\end{tabular}

Notes: Standard errors in parentheses. * significant at 5\%; ** significant at 1\%. Columns (1)-(3) are OLS regressions. Remaining columns are probit estimates with probability derivatives reported. 
Table 10: Restaurant Targeting and Income

\begin{tabular}{|c|c|c|c|c|c|c|c|c|c|c|c|}
\hline & (1) & $(2)$ & (3) & $(4)$ & $(5)$ & (6) & $(7)$ & $(8)$ & (9) & (10) & $(11)$ \\
\hline & $\begin{array}{l}\text { \# Sample } \\
\text { Chains }\end{array}$ & $\begin{array}{l}\text { Sitdown } \\
\text { Chains }\end{array}$ & $\begin{array}{l}\text { Fast Food } \\
\text { Chains }\end{array}$ & $\mathrm{CR} \$$ & CR \$ \$ & CR $\$ \$ \$+$ & Chicken & Pizza & Burger & Mexican & $\begin{array}{c}\text { Coffee, } \\
\text { bagel }\end{array}$ \\
\hline $\mathrm{HH}$ Inc $>40 \mathrm{k}$ & $\begin{array}{c}1.4859 \\
(0.0229)^{* *}\end{array}$ & $\begin{array}{c}0.3842 \\
(0.0085)^{* *}\end{array}$ & $\begin{array}{c}1.1017 \\
(0.0163)^{* *}\end{array}$ & $\begin{array}{c}0.0426 \\
(0.0013)^{* *}\end{array}$ & $\begin{array}{c}0.0355 \\
(0.0010)^{* *}\end{array}$ & $\begin{array}{c}0.0269 \\
(0.0009)^{* *}\end{array}$ & $\begin{array}{c}0.0396 \\
(0.0016)^{* *}\end{array}$ & $\begin{array}{c}0.1058 \\
(0.0025)^{* *}\end{array}$ & $\begin{array}{c}0.0907 \\
(0.0028)^{* *}\end{array}$ & $\begin{array}{c}0.0440 \\
(0.0014)^{* * *}\end{array}$ & $\begin{array}{c}0.0885 \\
(0.0019)^{* *}\end{array}$ \\
\hline $\mathrm{HH}$ Inc $<40 \mathrm{k}$ & $\begin{array}{c}0.9828 \\
(0.0262)^{* *}\end{array}$ & $\begin{array}{c}0.1499 \\
(0.0097)^{* *}\end{array}$ & $\begin{array}{c}0.8328 \\
(0.0186)^{* *}\end{array}$ & $\begin{array}{c}0.0216 \\
(0.0014)^{* *}\end{array}$ & $\begin{array}{c}0.0055 \\
(0.0011)^{* *}\end{array}$ & $\begin{array}{c}0.0036 \\
(0.0009)^{* *}\end{array}$ & $\begin{array}{c}0.0777 \\
(0.0021)^{* * *}\end{array}$ & $\begin{array}{c}0.0544 \\
(0.0025)^{* *}\end{array}$ & $\begin{array}{c}0.1107 \\
(0.0035)^{* *}\end{array}$ & $\begin{array}{c}0.0330 \\
(0.0015)^{* *}\end{array}$ & $\begin{array}{c}-0.0087 \\
(0.0017)^{* *}\end{array}$ \\
\hline Constant & $\begin{array}{c}0.0720 \\
(0.0780)\end{array}$ & $\begin{array}{l}-0.0425 \\
(0.0289)\end{array}$ & $\begin{array}{c}0.1145 \\
(0.0554)^{*}\end{array}$ & & & & & & & & \\
\hline $\begin{array}{l}\text { Observations } \\
\text { R-squared }\end{array}$ & $\begin{array}{c}14931 \\
0.53\end{array}$ & $\begin{array}{c}14931 \\
0.29\end{array}$ & $\begin{array}{c}14931 \\
0.58\end{array}$ & 14931 & 14931 & 14931 & 14931 & 14931 & 14931 & 14931 & 14931 \\
\hline
\end{tabular}

Notes: Standard errors in parentheses. * significant at 5\%; ** significant at 1\%. Columns (1)-(3) are OLS regressions. Remaining columns are probit estimates with probability derivatives reported. 